Spring 2015

\title{
Value and Hidden Cost in André Breton's Surrealist Collection
}

Katharine Conley

William \& Mary, kconley@wm.edu

Follow this and additional works at: https://scholarworks.wm.edu/aspubs

Part of the Art and Design Commons, and the Modern Art and Architecture Commons

\section{Recommended Citation}

Conley, Katharine, Value and Hidden Cost in André Breton's Surrealist Collection (2015). South Central Review, 32(1), 8-22.

https://www.doi.org/10.1353/scr.2015.0004

This Article is brought to you for free and open access by the Arts and Sciences at W\&M ScholarWorks. It has been accepted for inclusion in Arts \& Sciences Articles by an authorized administrator of W\&M ScholarWorks. For more information, please contact scholarworks@wm.edu. 


\title{
Value and Hidden Cost in André Breton's Surrealist Collection
}

\author{
Katharine Conley, College of William and Mary
}

A KEY ASPECT OF SURREALIST PRACTICE involved the collection of objects from near and far, of high and low value, objects found and purchased, natural or manmade, fashioned by themselves, their friends, or craftspeople from the Pacific Islands or the Pacific Northwest mingled with paintings by themselves and their friends along with such established artists and writers from previous generations as Henri Rousseau, Paul Gaugin, Paul Cézanne, Victor Hugo, and Gustave Moreau. ${ }^{1}$ They revived the baroque appetite for collecting things from around the world typical of the Age of Discovery as a way of expanding their own appreciation and knowledge of the world and of themselves. Most important for understanding the impact of surrealism on twentieth-century aesthetics was their development of a truly global aesthetic through the embrace of a twentieth-century version of the baroque. Indeed, their adoption of baroque enthusiasm for eclectic objects whose beauty was linked as much to their oddity and capability for surprise as to any Western notion of proportion, color, and quality, catalyzed and materially embodied their global ambition: their desire for their aesthetic to encompass and correlate their own principles to those of others geographically distant from themselves who also funneled their spiritual energies into objects. Moreover, their enthusiasm for collection was matched by their adoption of the baroque collector's love of mixing categories in one space.

The collection of André Breton, author of the two "Manifestoes of Surrealism," was in many ways closer to a baroque cabinet of curiosities or a personalized museum of ethnography than to a Parisian nineteenthor early twentieth-century museum of art [Fig. 1]. It thus also mirrored French colonialist enthusiasm over time for the acquisition of spoils from the lands and people colonized by France, just as France's status as an empire facilitated his acquisition of his collection. ${ }^{2}$ For Breton, his collection's monetary cost was minimal when measured against its significant emotional value, but he did not explicitly measure the moral cost of his economic investment in his psychically powerful things. That cost, which has become more visible following the advent of a post-colonial perspective, will be examined here for the way it exposes 


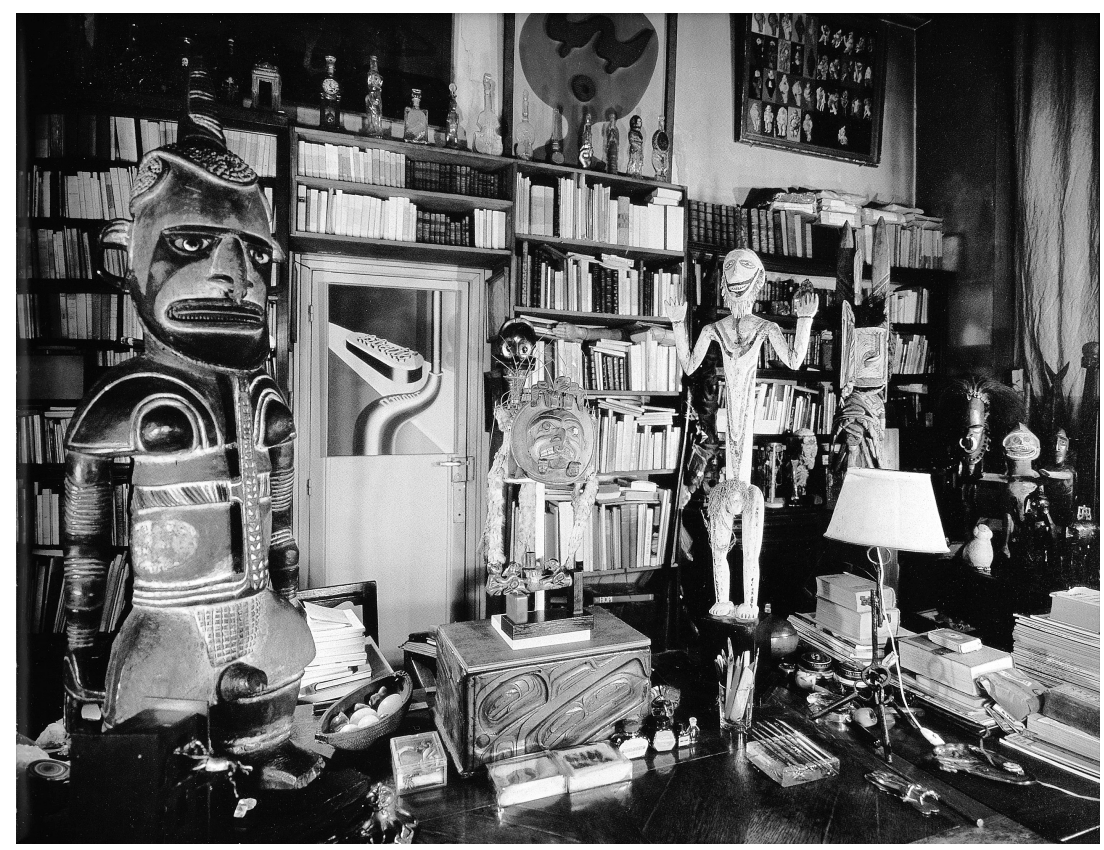

Figure I.André Breton's Desk, Photo: Gilles Ehrmann, 2003 @ Estate of Gilles Ehrmann/ SIAE, Pairs/VAGA, New York.

Breton's deeply personal and conflicted feelings about objects important to surrealism acquired thanks to French colonialism. Breton's sense of the value and cost of his collection exists in a pivotal tension at the heart of surrealism, balanced between his considerable vision and his openness to moral compromise. This tension was typical not only of Breton as an individual but of his century, throughout its history of empire and the dissolution of empire over the course of Breton's lifetime. This study of his relationship to his collection viewed in economic and moral terms thus situates surrealism itself at the heart of the fundamental shifts in ethical perspective about colonialism that took place over the course of the twentieth century.

Breton's collection provides a unique perspective on the environment within which the principles of surrealism were crystallized, including the economics of surrealist collecting. In addition to his European paintings, Breton's passion for Oceanic and North American objects grew from the 1920s until his death in September 1966, resulting in a remarkable and valuable collection. Some of the contents of his apartment at 42 , rue Fontaine, in the $9^{\text {th }}$ arrondissement in Paris are now displayed at the 
Pompidou Center as André Breton's Wall. The rest was auctioned off by his daughter Aube in a major sale in 2003. In an exhibition catalogue essay from 1948, Breton ascribed a "poetic (surrealist) vision" to the objects he collected, with no reference to their monetary value. ${ }^{3}$ He echoed this judgment of his objects as valuable for their poetic impact in other essays written about his collection in the 1950s and 1960s. And yet his history of acquisition and de-acquisition of objects shows that he also understood collecting as a form of financial investment.

This is the story of the evolving response to these objects by Breton and also by us, since 1966. It was only in 1968 that the "Primitivism" in $20^{\text {th }}$-Century Art exhibition, curated by William Rubin at the Museum of Modern Art in New York, sparked a heated debate about whether the objects displayed as important sources and influences on Western modern art had legitimate histories of their own. ${ }^{4}$ Even one of the most cited critiques of the exhibition, by Thomas McEvilley, still argued that these things were destined for destruction in their own cultures. McEvilley's perspective echoes Breton's own views, which were derived in part from published reports from the Trocadéro Museum of Ethnography's 1931 to 1933 collecting mission that crossed central Africa from Dakar, Senegal, to Djibouti on the Horn of East Africa. ${ }^{5}$ It took Sally Price's impassioned argument against this viewpoint in Primitive Art in Civilized Places, first published in 1989, to trigger a new way of thinking about the histories of these objects and their role in Western collections, particularly in museums. Price continued her critique of Western misunderstanding of the histories and value of non-Western works in her 2007 book on the Quai Branly Museum collection, Paris Primitive, a study that confirms we are still in the thick of this key post-colonial conversation. ${ }^{6}$ Looking back at how Breton started this conversation with his collection and publications about collecting finally gives him and the surrealists credit for launching a debate that remains unresolved to this day. ${ }^{7}$

Only in the 1980s did the sorts of things that "enthralled" Breton move out of ethnographic collections into museums of "art," around the same time that surrealist art began to be recognized as aesthetically important and valuable, beginning in 1968 with another historic show curated by Rubin at the Museum of Modern Art two years after Breton's death, Dada, Surrealism, and their Heritage. ${ }^{8}$ By 1968 , surrealism was no longer simply "contemporary," and began to warrant a legitimate place in museums like the Menil Collection, in Houston. ${ }^{9}$ This history is important because it lies at the root of the widespread global aesthetic that most Americans and Europeans now take for granted, an aesthetic that was pioneered by the surrealists and clearly visible in surrealist collections. 
From a twenty-first century perspective there is no doubt that the acknowledged - poetic - value of Breton's collection and its less acknowledged - monetary-value clearly show a contradiction between Breton's unproblematized understanding of art acquisition as a form of patronage and his intellectual rejection of active engagement in the bourgeois economy, so strongly expressed in 1928 in Nadja and in his explicitly anti-colonialist political stance, dating back to $1925 .{ }^{10} \mathrm{His}$ rejection of the legitimacy of the bourgeois economy governed his desire to remove non-Western objects from the marketplace as an act of rescue and preservation of their aesthetic autonomy. However, exemption from the bourgeois economy is truly only affordable for the wealthy. Most, including Breton himself, could not afford to live outside of the economy and this was particularly the case for the woman who inspired his book Nadja, Léona Delcourt, for whom Breton sold a painting in order to help her out financially, months before she was interned in a mental institution. ${ }^{11}$ Breton himself had trouble paying for the luxury of collecting. He remained oddly tone deaf to the contradiction between his social position as a collector and patron of the arts, rooted in his powerful desire for the feelings of enthrallment his collection gave him, and his desire to identify with the working class in alignment with his leftist politics, which ideologically opposed him to those who could afford the privilege of collecting. The language he uses to describe his feelings about fine art and objects reveals that, as a poet, he saw himself as a commentator and observer of culture, and thus exempted from this dichotomous opposition, as though his actions and his intuitive and instinctive feelings about his collection could somehow exist at a remove from his economic status as a collector. He embraced a view of himself as both an enthusiastic collector and a leftist intellectual opposed to the acquisition of wealth for its own sake. He also actively spoke out against the oppression of colonized people, even though some of his favorite objects, to which he had gained access as a result of colonialism, were originally made by individuals living inside the boundaries of the French empire.

In 1925, immediately following the publication of the first "Manifesto of Surrealism," he co-authored an anti-imperialist surrealist pamphlet that positioned him against his own government, in support of the rebels of the Rif Valley in Morocco, who were fighting for independence from France. His anti-colonialist position was confirmed in 1931, with his participation in a small exhibition created to refute the political assumptions of the major "Colonial Exhibition" taking place in Paris at the time, "The Truth about the Colonies," along with the two accompanying pamphlets he co-authored. ${ }^{12}$ Following his return to Paris in May 1946 
from his self-imposed exile in New York during World War Two, Breton co-authored another two pamphlets in support of the independence of the former colonies of Vietnam and Algeria from France. The first, "Liberty is a Vietnamese Word" (in English translation), came out in 1947, years before the French withdrew from Vietnam in 1954. In 1960 he joined his name to the "Manifesto of the 121" intellectuals and public figures who signed their support of Algeria's desire for independence from France, early in what the French came to call the Algerian War, which lasted until 1962.

For Breton, politics were inextricably linked to poetics, starting with his commitment to dada during World War One and that movement's antiwar stance. As he makes clear in Nadja, poetics were also inextricably linked to art for him, specifically the works in his personal collection, with which he illustrates the book dedicated to the woman who introduced herself to him as Nadja. He was drawn to Léona-Nadja, partly because of her uncanny ability to formulate aloud spontaneous feelings eerily in sync with his own, such her response to the Easter Island statue that had been his first purchase of non-Western art, made with prize money he had received for doing well on his baccalaureat in 1912. When she saw it, she exclaimed, "I love you, I love you," in a dramatic channeling of the statue's voice that uncannily mirrored his own attraction to it when he first saw and purchased it at the age of sixteen. ${ }^{13}$

Breton's teenage enchantment with non-Western objects was confirmed by his enchantment with his mentor Guillaume Apollinaire's apartment in Paris just a few years later. In 1952, on the radio, not long after his return to Paris from New York in 1946, Breton described in vivid detail his discovery of Apollinaire's apartment when he was a young man. The description reminds the reader familiar with Breton's apartment how closely his own combination of books, paintings, and non-Western and found objects resembled that of his erstwhile mentor: "The apartment was narrow [...] one had to wind one's way between the furniture and shelves holding numerous African or Polynesian fetish sculptures mixed with strange objects between stacks of books with their old-fashioned yellow covers, typical of books from that time [...] Along the low walls, paintings were hung so closely together there was practically no space in between them, each one providing a kind of escape to the viewer, a glimpse of adventurous possibilities or unknown worlds."14

Breton spent a lifetime enamored with art. In an article published in 1952 , he remembers his youthful response to works that at the time were unfashionable, that were "confronted with contempt and practically universal intolerance. The encounter with these works," he continues, 
"even mediocre photographic reproductions of them, transported me, it seemed to me, outside of myself, granting me the most exalting glimpse of the possible that was imaginable to me at the time." ${ }^{15}$ This sense of exaltation inspired a strong desire to possess the works in question. $\mathrm{He}$ explains how this desire was motivated by his wish to move newly acquired paintings freely around his apartment in order see them clearly and appreciate them from different angles, and his particular pleasure in temporarily hanging them on the wall facing his bed so that he could see them when he first woke up.

In the preface he wrote to the exhibition "Oceania" four years earlier in 1948, Breton expressed a similar desire to possess Oceanic objects, explaining this desire as "a compelling need." ${ }^{16}$ Citing this essay, Elizabeth Cowling confirms "Breton was not exaggerating when he wrote that many a trip abroad undertaken by himself and his friends was dictated wholly 'by the hope of discovering, at the cost of constant searching from morning to night, some rare Oceanic object." ${ }^{17}$ Breton credits Apollinaire for having also admired, owned, and displayed such objects in his apartment prior to World War One and for having mentioned his Oceanic "fetishes" in his 1911 poem "Zone," in which he established a new, modern aesthetic much admired by Breton. Breton describes how these objects emanate a kind of halo "that subjugates us" and how he felt the need to wake up with these objects, because of their ability to transport him elsewhere in a way that allowed him to be more fully himself and more fully in the present moment of his everyday life. "As for me," he writes, "I often need to come back to them, to watch them as I am waking up, to take them into my hands, to talk to them, to escort them back to their place of origin in my mind so as to reconcile myself to where I am." ${ }^{18}$ His delight in these things endured throughout his life, as he explains in that essay: "I am still as captivated by these objects as I was in my youth, when a few of us were instantly enthralled at the sight of them. The surrealist adventure, at the outset, is inseparable from the seduction, the thrall they exerted over us." 19

It is in his preface to the 1948 exhibition that he qualifies Oceanic objects as having perennial prestige within surrealism, emanating from a shared poetic vision. Most likely, it was a statement like this along with his confession later in the essay that he was "guilty, it seems, in some people's eyes, of continuing to be moved by the resources of the primitive soul," that prompted Evan Maurer to claim a "similar path" to have been followed by the surrealists as by so-called "primitive" people, in his 1968 essay on "Dada and Surrealism" in Rubin's controversial "Primitivism" show catalogue: "Primitive society found the answers to the questions 
of life in the spirit world and the realm of the dream. The Surrealists in studying Primitive arts and cultures, followed a similar path. ${ }^{20}$ It was indeed the poetic value of things, particularly his non-Western things, that in Breton's eyes justified their removal from their culture of origin. He supported André Malraux, for example, when Malraux got in trouble in 1924 for planning to steal some Khmer statues from Cambodia to bring them back to France. Breton's defense of Malraux was based in the principle of poetic value, which for him had supreme importance. As Clara Malraux explained in her memoir, Breton defended her husband in Les Nouvelles littéraires because she and her husband had "succumbed to desire, a surrealist principle." ${ }^{21}$

Jean-Claude Blachère poses Breton's contradictory attitude towards these objects as a dilemma, opposing the moral cost of plunder with the exalted value of "passion": "Even if one does not consider the collection of primitive objects as the creation of a cache of stolen goods, of things acquired in problematic circumstances, at best, does one not consider such collecting responsible for the dissolution of primitive cultures, for their slow erasure? Interesting dilemma, which opposes passion and desire against morality." 22 Breton's desire to keep non-Western things exceeded his need to care for his family during the lean 1930s, according to the painter Jacqueline Lamba, his second wife, in a letter from 1984 to Blachère. Lamba recalls the irony of being short of cash while living with Breton and their new baby Aube, surrounded by a treasure trove of valuable things that her husband refused to sell to make their lives more comfortable: "Years with little money, surrounded by a priceless collection. To be a collector to such an extreme, one knows, is a pathological phenomenon." ${ }^{23}$

So if the value of his collection was poetical for Breton to the point of being pathological in the eyes of his ex-wife and the cost was a deeply contradictory moral stance, what was his monetary relationship with these things? What did they cost him and what was his involvement with the market that made them accessible to him, a market regulated by the French Empire until well after World War Two? Louise Tythacott proposes an explanation in Surrealism and the Exotic:

the Surrealists [. . .] became prominent agents of the commodification [of exotic sculptures in the early decades of the twentieth century] through their close contacts with dealers and museum curators. Some worked for dealers and museums; others even worked as dealers and in museums. For example, 1921 found Breton working for the Parisian art collector Doucet, [for 
whom] he kept the library and helped expand his collections. This apparently financed Breton's acquisition of objects from other sources. ${ }^{24}$

It was at Breton's impassioned recommendation that the collector Jacques Doucet bought Pablo Picasso's Les Demoiselles d'Avignon, for example. For Breton, the painting was a reflection of the very "state of civilization" at the time, a time that also saw the publication of the first "Manifesto of Surrealism," December 1924. In his letter to Doucet, Breton writes "I cannot help but see in Les Demoiselles d'Avignon the most important event of the beginning of the twentieth century [. . .] For me, it is the purest of symbols, like the Chaldean Bull, the intense projection of a modern ideal that we still only comprehend in a fragmentary way." ${ }^{25} \mathrm{It}$ is not coincidental that in the painting Picasso mixes Western and nonWestern images (Western human faces and African masks) in a way that Breton would emulate with his collection. In his letter to Doucet, Breton exalts the painting as a "sacred image" with the full understanding that if Doucet follows his recommendation he will spend a lot of money on it; Picasso was a well-established artist by then. The poetics of the sacred and the economics of the market unite in Breton's advice, even if Breton's letter omits any explicit reference to the cost of the investment Doucet would need to make to acquire the painting.

Like most individuals after the Wall Street crash of 1929, Breton was forced to respond to the necessity of the market in 1931 when he participated in a major auction of his and Paul Eluard's non-Western objects at the Hôtel Drouot. The sale included a great quantity of African art owned by both men. According to Cowling, however, after the sale, Breton "never again bought anything African."26 The magnitude of what Tythacott calls this "monumental auction, [. . .] one of the most important primitive art auctions held in Paris between the wars," may have accounted for Breton's reluctance to sell any more of his precious things a few years later when he held onto his collection at the expense of a reasonable quality of life, despite marriage and fatherhood..$^{27}$ Breton and, to a much greater extent, Eluard, also served as a buyer for dealers, in particular Charles Ratton, the gallery owner who sponsored the weeklong "Surrealist Exhibition of Objects" in May 1936. Their friendship with Ratton was based on shared admiration for Oceanic and North American objects and it also had a commercial benefit for Breton, because Ratton bought advertising in the pioneer surrealist journals. "A page in the journal La Révolution surréaliste or its successor, Le Surréalisme au service de la révolution, was a way of financing the journal," explains 
Philippe Dagen in the catalogue to the exhibition at the Quai Branly Museum from 2013 dedicated to Ratton. "Selling and buying objects," Dagen continues, "was a way of directly supporting Breton and Eluard."28 However, while Breton may have traveled with Eluard to London and Holland and even purchased his first Yup'ik mask for Ratton, Cowling reports that in an interview Ratton told her that Breton was never much of a buyer for him, because Breton "would have wanted to keep all the best things for himself." ${ }^{29}$ Masks collected by Breton wound up in major museums, including the Quai Branly Museum collection and the Breton's Wall exhibit at the Pompidou Center. ${ }^{30}$

Breton and Lamba tried selling surrealist objects when they opened the Gradiva Gallery in Paris in 1937, as a way of making ends meet and in recognition of the financial value of the sorts of objects Breton liked to collect. But this venture failed, as Lamba explained in a letter, because neither she nor Breton had commercial experience. ${ }^{31}$ Blachère defends Breton against the accusation that he collected for monetary gain, however: "Everyone with a non-polemical perspective who knew Breton as a collector agrees that he was not doing it for the money," unlike some of his friends, who were clearly in the business of buying and selling non-Western objects for profit. ${ }^{32}$

Breton's collection benefitted enormously from the opportunity he found in a shop discovered by Max Ernst on Third Avenue in New York City run by Julius Carlebach and subsequently frequented by Ernst, Breton, Claude Lévi-Strauss and others in their circle. Carlebach had access to works from the Heye Foundation, which owned the Museum of the American Indian at the time. With George Heye's blessing, Carlebach eventually led them to a warehouse in the Bronx filled with the Foundation's "surplus" collection of works Heye did not take seriously. From that warehouse they were able to choose "masterworks as judged by the tribes that produced them," according to anthropologist Edmund Carpenter, for prices ranging from $\$ 38$ to $\$ 54$ apiece. ${ }^{33}$ For while Breton may have admired Native sculptures from the American West, the Pacific Northwest Coast, and the Arctic before he wound up in New York City during the war, he was able to indulge this passion with multiple acquisitions during his time in the United States.

Specifically, Breton's admiration for Hopi katchina dolls dates back to the $1920 \mathrm{~s}$, at least, as a reproduction of a katchina doll in a 1927 issue of La Révolution surréaliste indicates. He would have also been familiar with the value of Heye's collection before moving to New York, thanks to a show put on in Paris by Ratton in 1931 or 1932, of Northwest Coast and Eskimo masks that Ratton was able to acquire from Heye for "a small 
sum of money and a few pieces of Peruvian goldwork." ${ }^{34}$ The show attracted few visitors besides the surrealists and the only person to buy a mask was Man Ray, the day after the show closed. Breton later bought one, too, and included it in the 1936 "Surrealist Exhibition of Objects" in Ratton's gallery, along with four of the Eskimo masks left over from the earlier exhibition, on loan from Ratton, together with objects found and made by the surrealists themselves and their friends.

Breton's relationship to these pieces was "naively idealistic," according to Colin Browne, since "the argument that an object might belong in its place of origin hardly occurred to collectors in 1930; [although] today it cannot be ignored. ${ }^{\prime 35}$ For Breton, bringing such objects to New York and Paris as someone who appreciated their aesthetic value, and then making them available for view to a chosen group of initiates, was the right thing to do. He covered the upper wall of his sitting room with his collection of rare Hopi katchina dolls, for example, and the walls surrounding the desk in his study were covered with masks from the Pacific Northwest Coast and the Arctic and other objects from the Americas such as a Plains Indian leather shield and a box of small pre-Columbian statues $^{36}$ [Fig. 2]. He believed that Europeans needed such objects more

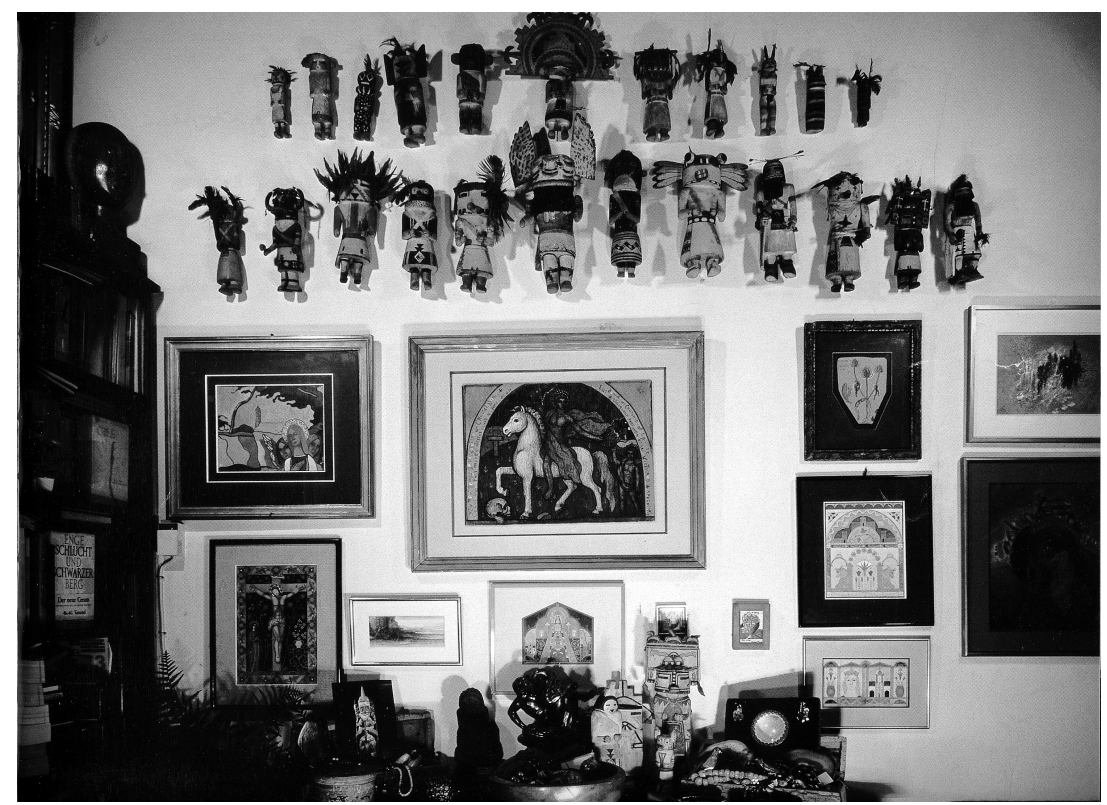

Figure 2. André Breton's Apartment, Photo: Gilles Ehrmann, 2003 @ Estate of Gilles Ehrmann/SIAE, Pairs/VAGA, New York. 
than those who made them, because he believed that those who made them would eventually destroy them as a matter of course. He saw the acquisition of masks as an act of rescue from certain neglect and destruction and also a noble act of protection of such things from the capitalist market where they would be traded for financial advantage only and not for poetic value, that is, their ability to confer the elusive sensation of exaltation. ${ }^{37}$ As he wrote in the conclusion to his 1960 essay "Phénix du masque" (Phoenix of the Mask): "To withdraw the mask from derisive comment and the stain of the carnival falls clearly within the surrealist plan. ${ }^{\prime 38}$ Breton's friend Vincent Bounoure confirmed in an interview with Blachère from 1982 that "Breton's approach was definitive: merchants degrade the magical value of an object. Everything possible must be done to preserve the object's original function." ${ }^{\prime 39}$

And yet, as Tythacott muses: "For all their anti-colonial proclamations, the Surrealists' ethnographic collections blatantly mirrored the geography of French colonial possession. These collections, in other words, were predicated upon the very colonial and capitalist distribution networks they despised." 40 This moral ambiguity, particularly as we consider their habits retrospectively, serves as the "cost" of Breton's devotion to collecting. And there did in fact exist an economic relation between poetic magic and monetary gain for Breton, according to the testimony of the husband of fellow surrealist poet Joyce Mansour, one of his constant companions in his search for the perfect objet insolite in the 1950s. Samir Mansour explains his understanding of Breton as a collector to Mansour's biographer Marie-Laure Missir: "At the time [...] Breton was above all a collector. One could argue that he lived off the sale of his objects more than the sale of his books. He spent two or three hours a day walking through the flea markets and visiting galleries. Joyce accompanied him. When he found something he didn't have the means to buy for himself, I bought it for him." ${ }^{\text {"41 }}$ Tythacott adds that by the 1950s, Breton had a collection of Inuit masks "that rivaled those in some European museums. ${ }^{\prime 2}$ He understood the monetary value of his collection but it was his investment of passion into it that prompted his widow Elisa to keep it intact in their apartment from the time of his death in 1966 to the time of her departure for a retirement home in the late summer of 1992 where it remained undisturbed until the auction of 2003.

Was Breton's perspective morally compromised? From our vantage point in 2014 the answer is an unequivocal "yes." Does it still have value, despite the moral cost? My answer would still be "yes," due to Breton's role in focusing attention on what is now understood as a global aesthetic that his practice of valuing and collecting objects from around the world 
helped initiate. In a recent article in The Chronicle of Higher Education, Peter N. Miller argues that in our own time there seems to be "a latent feeling" that Miller identifies as "an emotion that needs to be recognized and attended to," namely "that objects are somehow the past they narrate." ${ }^{43}$ That "feeling" to which Miller refers as attributable to our own "time" arguably originated with Breton and the surrealists, even though Breton was not the first poet-artist to collect art and objects from other cultures. The "feeling" for Breton was key to the sense that objects not only "are $[\ldots]$ the past" but that they are capable of helping living human beings understand their own pasts better because of the emotional and psychic relationship a human being can have with an object, as Breton so clearly explained in his essays from the 1950s and 1960s.

Breton, even more than his mentor Apollinaire or even Picasso, obsessively reflected on what he was doing and thinking and feeling with and about objects in print and he continuously made the effort to learn about the objects he collected and their cultures of origin, albeit not as assiduously as some of his more ethnographically-minded contemporaries such as Ernst. For Breton, collecting was not simply about acquisition, it was about relationship. He believed that his relationships to things that moved him could profoundly enrich his life and lead him closer to a clearer understanding of it, just as his writings about his feelings and thoughts about objects give us his readers a clearer understanding of his goals and those of the surrealist movement. Breton's thought process with regard to objects and their value to him unfolded over time in the public eye, with all his faults on view, particularly the moral compromises he made in the service of acquiring and keeping many objects in his collection-compromises that were quintessentially of his time in a balanced tension with his vision of a new kind of global aesthetic, which was ahead of his time.

Now, thanks to his daughter Aube, the Wall remains on display at the Pompidou Center. Also available are a detailed catalogue of the 2003 auction and a website created in 2004 to commemorate the Atelier André Breton $^{44}$ [Fig. 3]. Aube Breton Elléouët's view was that others should experience the wonder he saw and invested in his objects, so that despite his contradictory attitudes, typical of his generation, that spanned the heyday of the French Empire to its rapid post-World War Two demise, others might also experience a comparable moment of exaltation to those that so transported him and understand how important it is to consider the appeal of things from one's own familiar culture as they stand juxtaposed with things from unfamiliar, distant cultures in order to gain a better perspective of what it means to be an appreciator and consumer of culture, a citizen of the world, within a global context. 


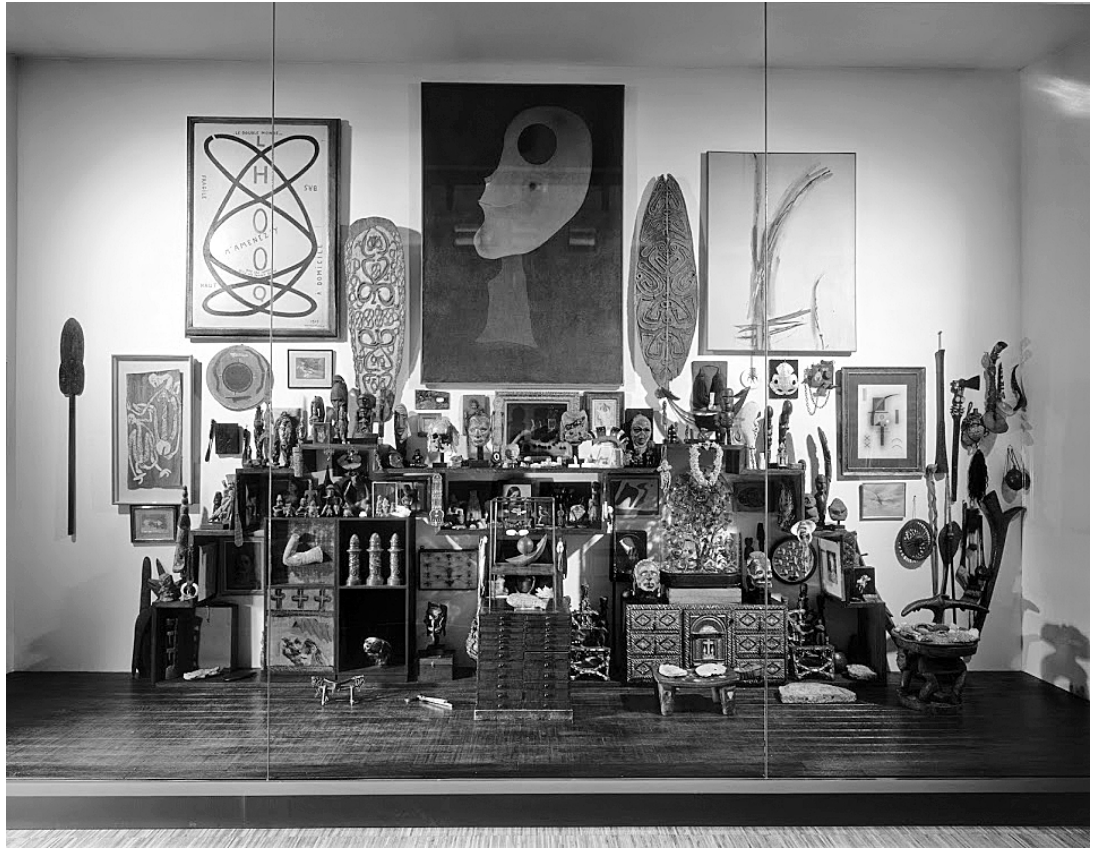

Figure 3.Wall of André Breton's Studio, Photo: Philippe Migeat. Musée National d'Art Moderne, Centre Georges Pomidou @ CNAC/MNAM/Dist. RMN-Grand Palais / Art Resource, NY.

\section{NOTES}

1. The artists listed here were all collected by André Breton. See the website dedicated to his collection, http://www.andrebreton.fr/. The contents of Breton's study and apartment were photographed and filmed in the 1990s by Gilles Ehrmann and published in a volume with a text by Julien Gracq prior to the 2003 auction of Breton's things. See Gracq, 42, rue Fontaine (Paris: Adam Biro, 2003).

2. See my "What Makes a Collection Surrealist: Twentieth-Century Cabinets of Curiosities in Paris and Houston," Journal of Surrealism and the Americas 6.1 (2012): 1-23; "Sleeping Gods in Surrealist Collections," Symposium 67.1 (2013): 6-24; and "Carrington's Kitchen," Papers of Surrealism 10 (2013): 1-18.

3. André Breton, "Oceania," in Free Rein, trans. Michael Parmentier and Jacqueline d'Amboise (Lincoln \& London: University of Nebraska Press, 1995), 171.

4. See William Rubin, "Primitivism" in 20 th -Century Art (New York: Museum of Modern Art, 1984). See also Jack Flam and Miriam Deutch, eds., Primitivism and Twentieth-Century Art, A Documentary History (Berkeley: University of California Press, 2003) and Sally Price, Primitive Art in Civilized Places (Chicago: University of Chicago Press, $1989+2001)$.

5. Thomas McEvilley, "Doctor, Lawyer, Indian Chief," in Flam and Deutch, Primitivism and Twentieth-Century Art, 347. Sometime surrealist Michel Leiris was on the Trocadéro Dakar-Djibouti Mission and published his surrealistic memoir, L'Afrique 
fantôme, to commemorate it. He also published an article in the surrealist-managed journal Minotaure in 1933, which he illustrated with a photograph of discarded masks after the dance ritual was complete. See "Masques Dogon," Minotaure 1.3 (1933): 45-51. Leiris partnered with Marcel Griaule on the guidelines for collecting objects on the mission, Instructions sommaires pour les collecteurs d'objets ethnographiques (Paris: Musée d'Ethnologie, 1931). See also Julia Kelly's excellent study, Art, Ethnography and the Life of Objects (Manchester: Manchester University Press-Palgrave, 207).

6. See Sally Price, Paris Primitive (Chicago: University of Chicago Press, 2007).

7. See my "Is Reconciliation Possible? Non-Western Objects at the Menil Collection and the Quai Branly Museum," South Central Review 27.3 (Fall 2010): 35-54.

8. Breton, "Oceania," 172.

9. See William Rubin, Dada, Surrealism, and Their Heritage (New York: Museum of Modern Art, 1968).

10. In Nadja, Breton expresses his belief that it is important to try to stay out of the bourgeois economy- "let no one speak to me of work," he exclaims. André Breton, Nadja, trans. Richard Howard (New York: Grove, 1960), 59.

11. Marguerite Bonnet, "Notice" [to Nadja], in André Breton, Oeuvres completes, t. 1 (Paris: Gallimard, 1988) 1512. Hester Albach writes about her discovery of Nadja's full name, in Léona, heroine du surréalisme, trans. Arlette Ounanian (Arles: Actes Sud, 2009), 50-51. Albach also refers to Breton having sold a painting, with his wife Simone's consent, in order to help Léona financially in December 1926, 168.

12. "Ne Visitez pas l'exposition colonial!" and "Premier bilan de l'exposition coloniale."

13. Breton, Nadja, 129 and 133. Dominique Berthet gives the date as 1912 in Berthet; see André Breton, L'Eloge de la rencontre. Antille, Amérique, Océanie (Paris : Editions HC, 2008) 35. Jean-Michel Gouthier gives the date as 1910 but it is in a letter where he makes another dating error so I have chosen the Berthet date; cited in Jean-Claude Blachère, Les Totems d'André Breton (Paris: L'Harmattan, 1996), 232. (Gouthier mistakenly gives the month of March as the date of return of Breton to Paris in 1946 when Blachère clarifies that it definitely was not until May in Blachère [232]).

14. My translation. André Breton, "Ombre non pas serpent mais d'arbre, en fleurs" (Shadow, not of a serpent, but of a tree, in flower), Oeuvres Complètes, t. 4 (Paris: Gallimard, 2008), 870-71. (This text was first read on the radio by Breton in 1952; see notes on the text by Etienne-Alain Hubert, 1400.)

15. My translation. André Breton, “'C'est à vous de parler, jeune voyant des choses"” ("Your turn to speak, young seer of things"), Oeuvres Complètes, t. 4 (Paris: Gallimard, 2008) 854.

16. Breton, "Oceania," 171.

17. Elizabeth Cowling, "L'Oeil sauvage': Oceanic Art and the Surrealists," Art of Northwest New Guinea, ed. Suzanne Greub (New York: Rizzoli, 1992) 180.

18. Breton, "Oceania," 174.

19. Ibid., 172.

20. Ibid., 172. Evan Maurer, "Dada and Surrealism," in Rubin, "Primitivism" in $20^{\text {th }}$-Century Art, 546.

21. My translation. Blachère, Les Totems d'André Breton, 139.

22. My translation. Ibid., 139.

23. My translation. Ibid., 138.

24. Louise Tythacott, Surrealism and the Exotic (London: Routledge, 2003), 93.

25. My translation. André Breton, in Les Demoiselles d'Avignon, vol. 2 (Paris: Editions de la reunion de musées nationaux, 1988), 590. 
26. Cowling, "'L'Oeil sauvage,"” 179.

27. See Tythacott, Surrealism and the Exotic, 96; and Maurer, "Dada and Surrealism," 546.

28. My translation. Philippe Dagen, "Ratton, objets sauvages," in Charles Ratton. L'invention des arts 'primitifs' (Paris: Flammarion-Musée du Quai Branly, 2013), 121.

29. Colin Browne, "Scavengers of Paradise," in The Colour of My Dreams, ed. Dawn Ades (Vancouver: Vancouver Art Gallery, 2011), 251. Also see Cowling, “'L'Oeil sauvage': Oceanic Art and the Surrealists," 179.

30. Masterpieces from the Musée du Quai Branly Collections (Paris: Quai Branly Museum, 2008), 86-87.

31. In Blachère, Les Totems d'André Breton, 138.

32. My translation. Ibid., 138. Dagen cites from Eluard's letters to his wife Gala in which he names prices for objects from New Guinea he has found and speculates on the profit he stands to gain from their sale. "Ratton, objets sauvages," 121.

33. Edmund Carpenter, "Introduction: Collecting Northwest Coast Art," in Form and Function, ed. Bill Holm and William Reid (Houston: Institute for the Arts, Rice University, 1975), 10. Martica Sawin recounts from interviews with some of the surrealists themselves that they were able to buy the masks from Heye "for sums averaging \$16 a variety of masks, kachinas, and carved objects from all regions of North America", in Surrealism in Exile and the Beginning of the New York School (Cambridge: MIT Press, 1994), 185. Patrick Wilken in his biography of Lévi-Strauss rounds the sum up to $\$ 50$, probably based on Carpenter's report in Claude Lévi-Strauss (New York: Penguin Press, 2010), 135. Elizabeth Cowling confirms this report in "The Eskimos, the American Indians, and the Surrealists," Art History 1.4 (1978) 493.

34. Cowling, "The Eskimos," 488.

35. Browne, 249.

36. See note 1.

37. Blachère's interpretation of Breton's passionate statement at the conclusion of "Phénix du masque" is to understand it as a statement about the responsibility of the surrealist to acquire an object in order to rescue it from a too likely fate: "that of getting destroyed out of missionary zeal or of getting purchased by a common merchant for profit." Les Totems d'André Breton, 141.

38. My translation. André Breton, "Phénix du masque," Oeuvres complètes, t. 3 (Paris: Gallimard, 2008), 93-94.

39. My translation. In Blachère," Les Totems d'André Breton, 209. As Cowling further explains in "'L'Oeil Sauvage"”: "In buying up Oceanic art in the curio shops, flea markets, and auction houses of Europe, the Surrealists were saving it from defiling hands. In exhibiting it alongside their own works, they were asserting its supreme value in their eyes" (181).

40. Tythacott, 96 .

41. My translation. Marie-Laure Missir, Joyce Manour. Une étrange demoiselle (Paris: Jean-Michel Place, 2005) 53-54.

42. Tythacott, 163.

43. Peter N. Miller, "How Objects Speak," Chronicle of Higher Education, accessed August 14, 2014, http://chronicle.com/article/How-Objects-Speak/148177/. This essay is part of a forthcoming book to be published in 2015 by Cornell University Press, An Intellectual History of Material Culture.

44. See note 1 for the website link. The auction catalogue was published in a boxed set: André Breton: 42, rue Fontaine (Paris: Calmels Cohen, 2003). 